\title{
Principals' Perceptions of the Importance of Technology in Schools
}

\author{
Hersh C. Waxman \\ Texas A\&M University, United States \\ Anna Witt Boriack \\ Texas A\&M University, United States \\ Yuan-Hsuan Lee \\ National Chiao Tung University, Taiwan \\ Angus MacNeil \\ University of Houston, United States
}

\begin{abstract}
A sample of 311 principals from a large metropolitan area in the southwest region of the $U$. S. responded to a questionnaire that addressed public school principals' perceptions related to the major functions of technology in their schools. Principals reported that the major functions of technology were: (a) communication, (b) instruction, (c) data sharing and management, (d) a resource, (e) administrative tasks, and (f) student learning. Male principals felt that technology was used as a resource and for administrative tasks more than female principals. Furthermore, principals with 12 or more years of experience perceived that technology was used for instruction, data sharing and management, and administrative tasks more than principals with less than 12 years of experience. These results indicate that both gender and years of experience influence how principals perceive the functions of technology in their schools. This could affect the technology leadership of principals, which may influence the success of technology implementation in schools.
\end{abstract}

Keywords: Technology use; Principals' use of technology; Educational technology; ICT in schools; Technology integration

\section{Introduction}

Recently there has been an increased interest on what successful school principals do in order to increase students' academic achievement and graduation rates (Day \& Leithwood, 2007; Schargel, Thacker, \& Bell, 2007; Waxman, MacNeil, \& Lee, 2006). Additional research has focused on principals' work, perceptions, and attitudes in order to determine if principals' behaviors influence student learning and teachers' behavior (Leithwood \& Riehl, 2005). Several other major national and international studies have highlighted the need to focus on principals' perceptions and attitudes toward leadership (Day \& Leithwood, 2007; Schargel, Thacker, \& Bell, 2007; Shen, 2005). 
Although technology is often viewed as a strategy that will facilitate students' academic achievement, there are many studies that have found that technology is not being integrated in schools, especially into the teaching and learning process (Cuban, 2001; Leonard \& Leonard, 2006; Padrón, Waxman, Lee, Lin, \& Michko, 2012). In order to encourage the integration of technology in schools, the International Society for Technology in Education (ISTE) developed the National Education Technology Standards (NETS) for students, teachers, administrators, technology coaches, and computer science teachers. The NETS for Administrators (NETS-A) contain five standards: (a) visionary leadership, (b) digital age learning culture, (c) excellence in professional practice, (d) systemic improvement, and (e) digital leadership. These standards are the skills and knowledge that school administrators and leaders need to successfully integrate technology in their schools (ISTE, 2009).

Several studies have suggested that school principals play a key role in determining whether or not technology is integrated in their schools. Ritchie (1996), for example, argues that the lack of administrative support negatively influences technology adoption and implementation in schools. On the other hand, principals who are more capable and comfortable using technology play a leading and supportive role in technology incorporation into the schools (Ritchie, 1996). Likewise, Sharratt (1999) maintains that the success of integrating information and communication technology in schools depends on the leadership and technological knowledge of the principal.

Teachers also perceive that school principals' attitudes toward technology are crucial in promoting technology integration in schools (Atkins \& Vasu, 2000). Coffland and Strickland (2004) investigated the relationship of teachers' attitudes and their principal's attitude on technology integration in a secondary geometry class. They found that principals' and teachers' attitudes toward computers were directly related and that teachers and principals with high attitudes towards technology tended to work together (Coffland \& Strickland, 2004). Additionally, Isabelle and Lapointe (2003) surveyed principals on their perceptions about integrating information and communication technology in schools. They found that principals who employed technology for pedagogical and technical purposes found it easier to incorporate technology in new instructional methods, were more supportive of teachers' pedagogical use of technology, and perceived that information technology would play a more important educational role in the future (Isabelle \& Lapointe, 2003).

Principal leadership has been found to be a prominent factor in integrating technology in schools. Baylor and Ritchie (2002) investigated the impact of seven factors related to school technology (planning, leadership, curriculum alignment, professional development, technology use, teacher openness to change, and teacher non-school computer use). Through administrative and teacher interviews, they found that student content acquisition was influenced in various ways by strong technology leadership. In addition, principals' positive attitudes toward technology encouraged both the incorporation of technology in classrooms and more frequent use of technology by teachers and students (Baylor \& Ritchie, 2002).

Furthermore, Anderson and Dexter (2005) analyzed a 1998 national survey of 866 principals and developed a technology leadership measure. This measure was based on eight technology-related activities and characteristics, such as the presence of a technology committee, principal email use, 
staff development policies, and a budget for school technology. The results generally showed that technology leadership had a significant, positive correlation with net usage (how frequently teachers and students used email and the internet), technology integration (how much teachers integrated technology into classroom practices), and student tool use (how often students used a computer to complete academic work). This suggests that administrators need to become technology leaders in their schools by using technology themselves, developing technology policies, and providing funding and training for new technology (Anderson \& Dexter, 2005). Chang (2012) surveyed 605 elementary teachers from Taiwan on their perceptions of their principals as a technology leader, along with teachers' technology literacy and overall teaching effectiveness. The results indicated that technology leadership by the principals increased technology literacy for the teachers. Principal technology leadership and technology literacy also improved teaching effectiveness. These findings suggest that principals should establish and implement technology plans for their school and become technology leaders in order to increase teachers' technology literacy and teaching effectiveness (Chang, 2012).

Despite research evidence that indicates that school leadership influences computer integration in schools, not many principals think their expertise in technology and attitude toward technology affects computer integration in schools. Brockmeier, Sermon, and Hope (2005) surveyed elementary, middle level, and high school principals in the state of Florida to examine principals' attitudes toward computer technology. They found that only $59 \%$ of the respondents indicated they agreed or strongly agreed that their technology expertise would affect them being viewed as a technology leader. Additionally, only $55 \%$ of participants agreed or strongly agreed to provide teachers release time to evaluate software appropriateness for integration into the curriculum. Generally, principals agreed that professional development is needed in some areas but not in others. A large percentage of principals, for example, responded that there was a need for professional development on: (a) assessing computer technology's influence on student achievement (85\%), (b) using computer technology to collect and analyze data (85\%), (c) integrating computer technology into the curriculum (84\%), (d) using computer technology in their work as a principal (80\%), and (e) using computer technology to facilitate organizational change (80\%). There was less agreement, however, among principals about receiving professional development on: (a) using computer technology for research purposes (69\%), (b) evaluating hardware (55\%), (c) evaluating software (54\%), and (d) developing budgets (48\%). Overall, Brockmeier et al. (2005) concluded that principals' technology expertise and their collaboration with teachers could speed up technology integration in schools. Also, principals should attend training on how to integrate technology into the teaching and learning process in order for them to assume a leadership role in technology integration in their schools (Brockmeier, Sermon, \& Hope, 2005).

Some studies have looked at specific aspects of technology such how electronic communication has changed the role of principals and school leaders. Hines, Edmonson, and Moore (2008) interviewed 10 principals on how electronic communication had impacted their role as principal. Twelve themes emerged which could be placed into two main topics: principal roles and computer-mediated communication. The themes under principal roles were: (a) an increase in the volume of information received; (b) more time spent at the computer; (c) more time spent working, especially at home; (d) being more accessible to staff and parents; (e) providing training for future principals on electronic communication; and ( $f$ ) providing training for staff on using 
electronic communication appropriately. The computer-mediated communication themes were: (a) changes in staff interaction, with less face-to-face communication occurring; (b) differences in the style and syntax used when communicating electronically; (c) the immediate and impulse properties of electronic communication, which leads to people sending emails with content that they would not have said in a face-to-face meeting; (d) the absence of social presence, which can lead to misunderstandings due to a lack of non-verbal cues; (e) the expectation of immediate responses making it difficult for principals to set boundaries between home and work; and ( $f$ ) complications related to legal issues, such as open records and student privacy. The increase in electronic communication may require a change in principals' roles. Current and future principals may need to learn how to manage time and information more effectively. They may also need to focus on making sure face-to-face communication is occurring with their staff (Hines, Edmonson, \& Moore, 2008).

Other studies have focused on some of the ethical, legal, and moral issues that school principals encounter when integrating technology in schools (Garland, 2010). Leonard and Leonard (2006) specifically examined 214 principals' perceptions of technology planning, access, orientations, and skills and found that technology integration remains problematic and that many school administrators do not feel that they are well prepared to be technology leaders. To gain insight into how technology integration occurs in schools, Peck, Mullen, Lashley, and Eldridge (2011) studied a technology-rich high school during the 2008-2009 school year. Data were collected through observations; documentation (i.e., handbooks, technology policies, and lesson handouts); and interviews with teachers, staff, and students. The study found three major challenges that were faced when implementing technology: (a) weak support structures that affected the implementation and maintenance of technology, (b) teachers' conflicting roles of encouraging technology use while also discouraging the students use of personal media devices (i.e., cell phones and MP3 players), and (c) students with more technology knowledge than teachers that were able to find ways around school rules (Peck, Mullen, Lashley, \& Eldridge, 2011). Based on these results, the authors made five recommendations for technology implementation: (a) plan for long-term technology support, (b) consider teacher technology needs before purchasing and implementing new technology, (c) encourage informal technology support networks, (d) allow teachers to demonstrate and share their successes of integrating technology into their instruction, and (e) adopt personal media device use guidelines for students that allow them to use devices during lunch and between classes and allow teachers to decide how the devices can be used in their classrooms. The recommendations should be considered by school administrators when implementing new technology in order to make the implementation process smoother for all involved (Peck, Mullen, Lashley, \& Eldridge, 2011).

\section{Purpose of the Study}

Although there is some research documenting school principals' perceptions of the technology, there are few studies that specifically focus on how principals view the importance of technology. The few studies that have examined principals' perspectives on technology planning, access, and orientations used survey questions that required narrow, dichotomous yes or no responses (e.g., Leonard \& Leonard, 2006). The present study builds on the prior research and includes an openended, cognitive interview question that allows for the examination of principals' perspectives and 
orientations toward technology. Furthermore, while other studies have explored differences by type of school, the present study focuses on principal characteristics such as years of experience and gender. There have been relatively few studies that have examined the influence of gender and experience on principals' use of computers (Serhan, 2009). The present study specifically examines the following two research questions: (a) What are principals' perceptions of the importance of technology? and (b) Do principals' perceptions of technology differ by years of experience and gender?

\section{Methodology}

A convenience sample of 310 principals from a large metropolitan area in the southwest region of the United States responded to a cognitive interview questionnaire that asked principals about their perceptions regarding the importance of technology for their schools. The sample consisted of 126 males and 184 females. A range of years of experience was present with 104 participants having 0-3 years of experience, 82 participants having 4-7 years, 55 participants having 8-11 years, 32 participants having 12-15 years, and 31 participants having greater than 15 years of experience.

The questionnaire was administered by graduate students in the Educational Leadership program at a major, urban doctoral-granting university located in the south central region of the U.S. As part of the principal's certification course requirements, students were trained on how to administer the instrument and required to interview a specific number of current public school principals. The survey instrument was designed specifically for this purpose and included both qualitative and quantitative questions.

As previously discussed, principals' cognitions and perceptions have been found to be valid and reliable and the use of cognitive interviewing further improves the validity of the data (Desimonte \& Le Floch, 2004). For this study, only the data from the interviews was used. The interview questions were "Has technology had an impact in your school?" and "If so, in what specific ways has it made a difference?"

Analysis of the interview data began with a process of data reduction. The participants' responses were read several times to become familiar with the data. The data was then coded into meaningful categories. Once the categories were established, another researcher independently coded a $10 \%$ sample of responses to determine the consistency of the coding. The inter-coder reliability results revealed a high level of agreement (Cohen's kappa $=.94)$.

\section{Findings}

The principals' responses for the major functions of technology were grouped into six categories. About one-third (35\%) of the principals indicated that technology was used as a primary communication tool. One principal, for example, stated, "Technology helps with sending out newsletters using an e-mail blast system, and teachers can e-mail parents to communicate in a more improved way." Another principal said, "Communication within the building and within the district is quicker and more accurate." Over one-quarter (28\%) of principals responded that 
technology was integrated in teachers' classroom instruction. This was discussed by one principal "The school's computer lab also plays a big role in teaching kids; through collaboration between the computer teacher and the classroom teacher, instruction can be planned for to reteach particular learning objectives stemming from the classroom." The third category was using technology for data sharing and management (14\%). One principal commented, "We can access data quick and fast and use it to make instructional decisions therefore impacting student learning for the better." Category four was using technology as a resource to find information (15\%) and a principal shared, "It [technology] reduces the time to reach resources and also increases the number of resources." Technology was also used for administrative tasks, such as taking attendance (10\%). A principal said, "Technology is a wonderful tool. It has increased our efficiency with record keeping, developing instructional materials, and numerous administrative tasks." Finally, technology was used for student learning (10\%). A principal felt that technology "For students, when utilized sufficiently, can provide tremendous steps to learning, learning how to find information and what to do with it." Table 1 displays the overall results of principals' perceptions of their major functions of technology.

Table 1. Principals' Perceptions of the Major Function of Technology

\begin{tabular}{lc}
\hline Major Function of Technology $(n=310)$ & $\%$ \\
\hline Communication & 34.5 \\
Instruction & 27.7 \\
Data sharing and management & 13.6 \\
Resource & 14.5 \\
Administrative tasks & 10.0 \\
Student learning & 9.7 \\
\hline
\end{tabular}

Note. Percentages do not add up to 100 since some responses were in more than one category.

The results for the major functions of technology by gender are shown in Table 2. When examining the major functions of technology by gender, the highest percentage of males and females discussed using technology for communication (33\% and $36 \%$, respectively). The next highest percentage of males and females felt that technology was used for instruction (33\% and $25 \%$, respectively).

Table 2. Principals' Perceptions of the Major Function of Technology by Sex

\begin{tabular}{lrr}
\hline Major Function of Technology & Male $(n=126)$ & Female $(n=184)$ \\
\hline Communication & $32.5 \%$ & $35.9 \%$ \\
Instruction & $32.6 \%$ & $24.6 \%$ \\
Data sharing and management & $15.0 \%$ & $15.2 \%$ \\
Resource & $15.9 \%$ & $13.6 \%$ \\
Administrative tasks & $12.0 \%$ & $8.7 \%$ \\
Student learning & $7.2 \%$ & $11.5 \%$ \\
\hline
\end{tabular}

Note. Percentages do not add up to 100 since some responses were in more than one category. 
Males and females differed in their perceptions of the other four categories. In order of decreasing percentage for males the last four categories were using technology: as a resource (16\%), for data sharing and management (15\%), for administrative tasks (12\%), and for student learning (10\%). The percentages for females in decreasing order were using technology: for data sharing and management $(15 \%)$, as a resource $(14 \%)$, for student learning $(12 \%)$, and for administrative tasks $(9 \%)$.

Finally, principals' perceptions of the major functions of technology were examined by years of experience: 0-3 years, 4-7 years, 8-11 years, 12-15 years, and more than 15 years. The two major functions of technology with the highest percentage were communication and instruction. The highest percentage for principals with 0-3, 4-7, and 8-11 years of experience was in communication (39\%, 33\%, and $31 \%$, respectively) followed by instruction $(24 \%, 30 \%$, and $24 \%$, respectively). Principals with $12-15$ and more than 15 years of experience had the highest percentage in instruction ( $31 \%$ and $39 \%$, respectively) followed by communication ( $28 \%$ and $36 \%$, respectively). The other four categories showed varied percentages by years of experience and they are displayed in Table 3.

Table 3 Principals' Perceptions of the Major Function of Technology by Years of Experience

\begin{tabular}{lrrrrr}
\hline Major Function of Technology & $\begin{array}{r}0-3 \text { Yrs } \\
(n=104)\end{array}$ & $\begin{array}{r}4-7 \text { Yrs } \\
(n=82)\end{array}$ & $\begin{array}{r}8-11 \text { Yrs } \\
(n=55)\end{array}$ & $\begin{array}{r}12-15 \text { Yrs } \\
(n=32)\end{array}$ & $\begin{array}{r}>15 \text { Yrs } \\
(n=31)\end{array}$ \\
\hline Communication & $38.5 \%$ & $32.9 \%$ & $30.9 \%$ & $28.1 \%$ & $35.5 \%$ \\
Instruction & $24.1 \%$ & $30.4 \%$ & $23.6 \%$ & $31.3 \%$ & $38.7 \%$ \\
Data sharing \& Management & $10.6 \%$ & $18.3 \%$ & $14.6 \%$ & $21.9 \%$ & $19.4 \%$ \\
Resource & $21.2 \%$ & $7.3 \%$ & $9.1 \%$ & $12.5 \%$ & $25.8 \%$ \\
Administrative tasks & $6.7 \%$ & $12.2 \%$ & $3.6 \%$ & $15.6 \%$ & $19.4 \%$ \\
Student learning & $9.6 \%$ & $14.6 \%$ & $3.6 \%$ & $12.5 \%$ & $6.4 \%$ \\
\hline
\end{tabular}

Note. Percentages do not add up to 100 since some responses were in more than one category.

\section{Conclusion}

As society increases as a technology-rich environment, school leaders are faced with how to support the integration of technology into meaningful learning activities and how to evaluate the use of technology within their schools (Yu \& Durrington, 2006). MacNeil and Delafield (1998) found that when administrators act as technology leaders, the teachers and students integrate and use technology more successfully. Yet many school administrators are novice technology users and have little experience or training in the knowledge and skills required to be effective technology leaders (Ertmer, Bai, Dong, Khalil, Park, \& Wang, 2002). To help teachers integrate technology, school leaders need to keep up with the latest technology. Without this knowledge, administrators find it difficult to help teachers understand the use of technology in the classroom. Additionally, Paben (2002) indicated that school leaders' visions for their schools must include technology. Schmeltzer (2001) argues that administrators need a broad set of experiences; they need to develop an understanding of how technology can improve instructional practices and a repertoire of strategies for supporting teachers' efforts to use technology in the classroom. 
The results from the present study suggest that principals view technology as important for carrying out communication and instruction. They also see the importance of using technology for data sharing and management, as a resource, for administrative tasks and for student learning. This indicates that principals have a positive view of technology and are using technology themselves. As shown in previous studies (Anderson \& Dexter, 2005; Baylor \& Ritchie, 2002; Chang, 2012; Isabelle \& Lapointe, 2003; Ritchie, 1996; Sharratt, 1999) the principals' positive attitudes towards technology and use of technology is viewed by teachers as being supportive of integration of technology into the classroom. In this way principals are becoming technology leaders, whether they realize it or not. None of the principals in the study, however, discussed their vision of the role of educational technology in their schools. Principals need to take a leadership role in planning for the purchase and implementation of new technology (Anderson \& Dexter, 2005; Peck, Mullen, Lashley, \& Eldridge, 2011). Future studies need to explicitly investigate principals' visions for educational technology in order to better understand if principals are truly technology leaders in their schools. Additionally, principals' perceptions of the major functions of technology differed by sex and years of experience. A previous study (Serhan, 2009) also found differences in principals' use and perceptions of technology by sex and years of experience. Future studies should further examine these differences to determine why they are occurring and how they might influence technology leadership. This study is limited in that it was only done in one metropolitan region in the southwest. Future studies should look at principals in other geographic regions and from different types of schools (e.g., public, private, and charter).

The present study indicates that principals' perceptions of the major functions of technology in their schools are varied by sex and years of experience. This may influence the leadership that principals provide when implementing technology in their schools and needs to be studied further in order to better understand the implications for technology use in schools. Principal preparation programs may want to consider addressing technology leadership so that school leaders are better prepared to effectively implement technology in their schools (Hines, Edmonson, \& Moore, 2008). Furthermore, schools should provide funding and opportunities for principals to attend technology training. This could increase their technology leadership and lead to better implementation of technology in entire schools. This study provides insight into principals' perceptions of technology importance but further research is needed to fully address the issue of how these perceptions influence technology leadership.

\section{References}

Anderson, R. E. \& Dexter, S. (2005). School technology leadership: An empirical investigation of prevalence and effect. Educational Administration Quarterly, 41, 49-82.

Atkins, N. E. \& Vasu, E. S. (2000). Measuring knowledge of technology usage and stages of concern about computing: A study of middle school teachers. Journal of Technology and Teacher Education, 8, 279-302.

Baylor, A. L. \& Ritchie, D. (2002). What factors facilitate teacher skill, teacher morale, and perceived student learning in technology-using classrooms? Computers \& Education, 39, 395-414. 
Brockmeier, L. L., Sermon, J. M., \& Hope, W. C. (2005). Principals' relationship with computer technology. NASSP Bulletin, 89(643), 45-63.

Chang, I-H. (2012). The effect of principals' technological leadership on teachers' technological literacy and teaching effectiveness in Taiwanese elementary schools. Educational Technology \& Society, 15, 328-340.

Coffland, D. A. \& Strickland, A. W. (2004). Factors related to teacher use of technology in secondary geometry instruction. Journal of Computers in Mathematics and Science Teaching, 23, 347-365.

Cuban, L. (2001). Oversold and underused. Cambridge, MA: Harvard University Press.

Day, C. \& Leithwood, K. (Eds.). (2007). Successful principal leadership in times of change: An International perspective. New York: Springer.

Desimonte, L. M. \& LeFloch, K. C. (2004). Are we asking the right questions? Using cognitive interviews to improve surveys in education research. Educational Evaluation and Policy Analysis, 26, 1-22.

Ertmer, P. A. , Bai, H., Dong, C., Khalil, M., Park, S. H., \& Wang, L. (2002). Online professional development: Building administrators' capacity for technology leadership. Journal of Computing in Teacher Education, 19(1), 5-11.

Garland, V. E. (2010). Emerging technology trends and ethical practices for the school principal. Journal of Educational Technology Systems, 38(1), 39-50.

Hines, C., Edmonson, S., \& Moore, G. W. (2008). The impact of technology on high school principals. NASSP Bulletin, 92(4), 276-291.

International Society for Technology in Education. (2009). National Education Technology Standards for Administrators. Retrieved on 10 March 2013 from http://www.iste.org/ docs/pdfs/nets-a-standards.pdf

IsaBelle, C. \& Lapointe, C. (2003). Start at the top: Successfully integrating information and communication technologies in schools by training principals. The Alberta Journal of Educational Research, 49, 123-137.

Leithwood, K. \& Riehl, C. (2005). What we know about successful school leadership. In W. Firestone \& C. Riehl (Eds.), A new agenda: Directions for research on educational leadership (pp. 12-27). New York: Teachers College Press.

Leonard, L. J. \& Leonard, P. E. (2006). Leadership for technology integration: Computing the reality. The Alberta Journal of Educational Research, 52(4), 212-224.

MacNeil, A. J. \& Delafield, D. P. (1998). Principal leadership for successful school technology implementation. In S. McNeil, J. D. Price, S. B. Mehall, B. Robin, \& J. Willis (Eds.), Technology and teacher education annual 1998 (pp. 296-300). Norfolk, VA: AACE.

Paben, S. (2002). What's in it for the busy leader? Show administrators how technology works toward their vision. Journal of Staff Development, 23(1), 24-27. 
Padrón, Y. N., Waxman, H. C., Lee, Y. H., Linn, M. F., \& Michko, G. (2012). Classroom observations of teaching and learning with technology in urban elementary school mathematics classrooms serving English language learners. International Journal of Instructional Media, 39(1), 45-54.

Peck, C., Mullen, C. A., Lashley, C., \& Eldridge, J. A. (2011). School leadership and technology challenges: Lessons from a new American high school. AASA Journal of Scholarship and Practice, 7(4), 39-51.

Ritchie, D. C. (1996). The administrative role in the integration of technology. NASSP Bulletin, $80(582), 42-52$.

Schargel, F. P., Thacker, T., \& Bell, J. (2007). From at-risk to academic excellence: What successful leaders do. Larchmont, NY: Eye on Education.

Schmeltzer, T. (2001). Training administrators to be technology leaders. Technology and Learning, 21(11), 16-24.

Serhan, D. (2009). The influence of gender and experience on school principals' computer use. International Journal of Instructional Media, 38(2), 153-162.

Sharratt, L. (1999). Technology implementation: Lessons for school and district leaders. Orbit, 30, 36-39.

Shen, J. (Ed.). (2005). School principals. New York: Peter Lang.

Waxman, H. C., MacNeil, A., \& Lee, Y. H. (2006, November). Principals' perceptions of successful school leadership. Paper presented at the annual convention of the University Council of Educational Administration, San Antonio, TX.

Yu, C. \& Durrington, V. A. (2006). Technology standards for school administrators: An analysis of practicing and aspiring administrators' perceived ability to perform the standards. NASSP Bulletin, 90, 301-317.

Correspondence: Hersh Waxman, Director of the Education Research Center, College of Education and Human Development, Texas A\&M University, College Station, Texas, United States 